\title{
99mTc-Anionic Linear Globular Dendrimer-G2- Phenylalanine Conjugate: Novel Brain Tumor SPECT Imaging
}

\author{
Rahimeh Rasouli ${ }^{1,2, *(D)}$, Farzaaneh Zaaeri ${ }^{3}$ (D) , Ahmad Bitarafan Rajabi ${ }^{4}$, Amir Darbandi-Azar ${ }^{4}$, \\ Reza Faridi-Majidi ${ }^{5}$ (D), Mehdi Shafiee Ardestani ${ }^{6}$
}

1 Department of Medical Nanotechnology, International Campus, Tehran University of Medical Sciences, Tehran, Iran; rrasouli@ razi.tums.ac.ir (R.R.);

2 Students' Scientific Research Center, Tehran University of Medical Sciences, Tehran, Iran;

3 Department of Pharmaceutics, Faculty of Pharmacy, Tehran University of Medical Sciences, Tehran, Iran; farzanehzaeri@yahoo.com (F.Z.);

4 Department of Nuclear Medicine, Cardiovascular Intervention Research Center, Rajaie Cardiovascular Medical and Research Center, Iran University of Medical Sciences, Tehran, Iran; bitarafan@hotmail.com (A.B.R.); amir.doc60@gmail.com (A.D.A);

5 Department of Medical Nanotechnology, School of Advanced Technologies in Medicine, Tehran University of Medical Sciences, Tehran, Iran; refaridi@ sina.tums.ac.ir (R.F.M.);

6 Department of Radiopharmacy and Medicinal Chemistry, Faculty of Pharmacy, Tehran University of Medical Sciences, Tehran; shafieeardestani@tums.ac.ir (M.X.Z.);

* Correspondence: r-rasouli@ razi.tums.ac.ir;

Scopus Author ID 55630317300

Received: 6.11.2020; Revised: 4.12.2020; Accepted: 7.12.2020; Published: 10.12.2020

Abstract: The purpose of this study was the investigation of the targeting potential of ${ }^{99 \mathrm{~m} T c-L a b e l e d}$ dendrimer-phenylalanine conjugate for brain tumor SPECT imaging. L-Type amino acid transporters (LAT1) are highly expressed in the blood-brain barrier as well as in brain cancer cells; thus, targeting LAT1 using phenylalanine could improve the sensitivity and specificity of radiosynthesis nanocarrier. In this study, the dendrimer G2-phenylalanine conjugate was synthesized and characterized by Fourier transform infrared spectroscopy, atomic force microscopy, particle size, and zeta potential. MTT assay was done for cell viability measurement in different concentrations of nanoparticles $(0.125,0.25,0.5$ $\mathrm{mg} / \mathrm{ml}$ ) on C6 glioma cell lines; the uptake study was evaluated using fluorescence-activated cell sorter (FACS) instrument; finally, SPECT scintigraphy in glioma tumor-bearing Wistar rats was done. The dendrimer-phenylalanine conjugate particle size was found in the range of $74.14 \pm 2.2$ to $109 \pm 3.1 \mathrm{~nm}$, with a slightly negative surface charge. Also, phenylalanine present on the dendrimer's surfacephenylalanine conjugate enhanced the dendrimer's cellular uptake-phenylalanine conjugate on the C6 glioma cell line. Results of SPECT imaging and fluorescence studies revealed that dendrimerphenylalanine conjugate accumulated into the brain tumor cells, and it can be suggested as a promising brain-targeting probe with no toxicity in brain tumor imaging.

Keywords: dendrimer G2; LAT1; phenylalanine; glioma; carrier-mediated transport; SPECT.

(C) 2020 by the authors. This article is an open-access article distributed under the terms and conditions of the Creative Commons Attribution (CC BY) license (https://creativecommons.org/licenses/by/4.0/).

\section{Introduction}

Malignant glioma such as glioblastoma multiform (GBM) is one of the most significant challenges in front of cancerous patients worldwide. World Health Organization (WHO) has categorized gliomas based on histological characteristics as grades I-IV. A WHO grade IV glioma is glioblastoma. Glioblastoma (GBM) is the most malignant grade and most common 
primary brain tumor [1-5]. The average patient's survival is about 1.5 years despite typical treatments, including surgery, chemotherapy with alkylating agents such as temozolomide, and ionizing radiation. However, early detection of cancer greatly increases the chance of successful treatment and survival. To diagnose cancer at the earliest stage, novel, and more effective targeted therapeutic and diagnostic agent delivery systems are needed [6,7]. Most therapeutic and contrast agents do not readily permeate the blood-brain barrier (BBB) $[8,9]$. $\mathrm{BBB}$ trafficking is the main limiting factor for delivering potential CNS drugs into the brain parenchyma, which makes it the interest of CNS drug designing. BBB is configured from capillary endothelial cells with tight intercellular junctions and surrounded by a basement membrane, astrocytes, and pericytes. BBB has a high electrical resistivity, 1500-2000(1300) $\Omega \mathrm{cm}^{2}$ (compared with other organs having an average resistance of $1.8 \Omega \mathrm{cm}^{2}$ ). Tight junctions and basal membranes are responsible for the integrity and maintenance of the barrier [1012](Figure 1). Some parameters should be considered for designing ideal carriers, including tight junction, electrical resistance, efflux proteins, and catalyzing enzymes [13,14]. For passive diffusion from BBB, hydrophobic, and hydrophilic agents' molecular weight must be less than 400-600 KDa with less than 8-10 hydrogen bands [15-18]. In addition, since diffusion depends on concentration, high concentration in capillary promotes diffusion. Due to these restrictions, $98 \%$ of small molecules and $100 \%$ of large molecules like antibodies, even engineering antibodies (around 15-150 KDa) do not pass BBB. These mentioned mechanisms are responsible for $98 \%$ of drugs that can not pass BBB [19-21]. It could be concluded that small lipophilic molecules with less protein binding (PB) and long serum half-life are good candidates to cross BBB. With this regard, lipophilicity, size, and ionization degree should be considered in designing BBB trafficable agents [22]. Carrier is conjugated to amino acids, glucose, nucleosides, or bigger molecules like insulin and transferrin to pass BBB [23,24]. Therapeutic or contrast agent delivery based on tumor cells' metabolism has shown significant success in recent years [25-33]. Amino acids are essential for cell growth and proliferation [34]. The L-type amino acid transporter-1 (LAT-1) can transport large, branched-chain and aromatic, neutral amino acids. Previous studies have shown a relationship between LAT1 level and tumor growth [35,36]. LAT1 expression is increased in several cancers [37-44]. Several studies have recently demonstrated the effectiveness of LAT-1 targeting for drug and contrast agent delivery in a wide range of cancers like breast cancer and glioma [25-33,45-53].

Recent studies have shown that the expression of LAT1 increases in glioma. Phenylalanine is an essential amino acid required for protein synthesis and is one of the LAT1 substrates. Therefore, targeting glioma cancer cells with the Phenylalanine ligand is suitable for targeting cancer cells [33,54-56].

Today, nanoparticles in disease diagnosis and therapy are an interesting field for researchers [27,57-71]. Nanoparticles can enhance drug dissolution; because of their small size, they can cross the membrane barrier. Another advantage is the possibility of particles targeted in a particular organ. Dendrimers are a family of compact spherical polymers at the nanoscale. They have numerous and diverse applications, including the biomedical field (i.e., drug delivery, cancer diagnostics). In this study, anionic G2 dendrimer (polyethylene glycol-citric acid) was synthesized using a simple method without the use of toxic and harmful agents.

Several modalities such as SPECT, PET, CT, and MRI have been introduced in metabolic imaging [72-76]. The purpose of this study was the investigation of ${ }^{99 \mathrm{~m}}$ Tc-labeled dendrimer-phenylalanine conjugate potential for brain tumor SPECT imaging. L-Type amino acid transporters (LAT1) are highly expressed on the blood-brain barrier as well as on many 
brain cancer cells, thus targeting LAT1 using phenylalanine improved sensitivity and specificity of radiosynthesis nanocarrier

In the present research work, an L-type amino acid transport system was utilized to cross BBB. The phenylalanine was used as a targeting ligand, which was conjugated on the dendrimer's surface labeled with ${ }^{99 \mathrm{~m}} \mathrm{Tc}$ as shown in Figure 2.

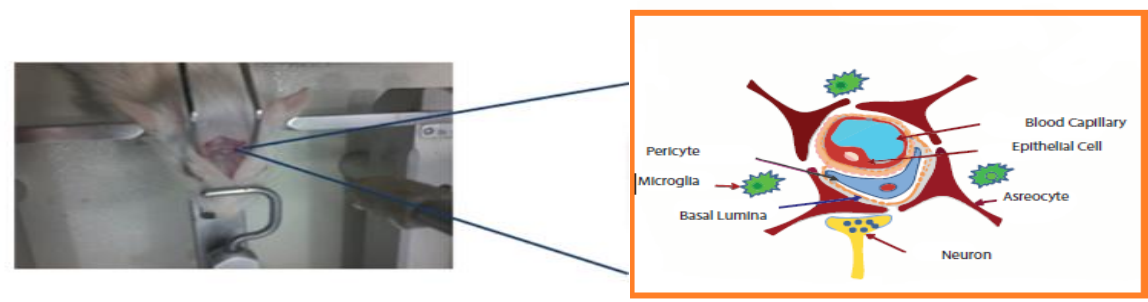

Figure 1. Schematic structure of BBB.

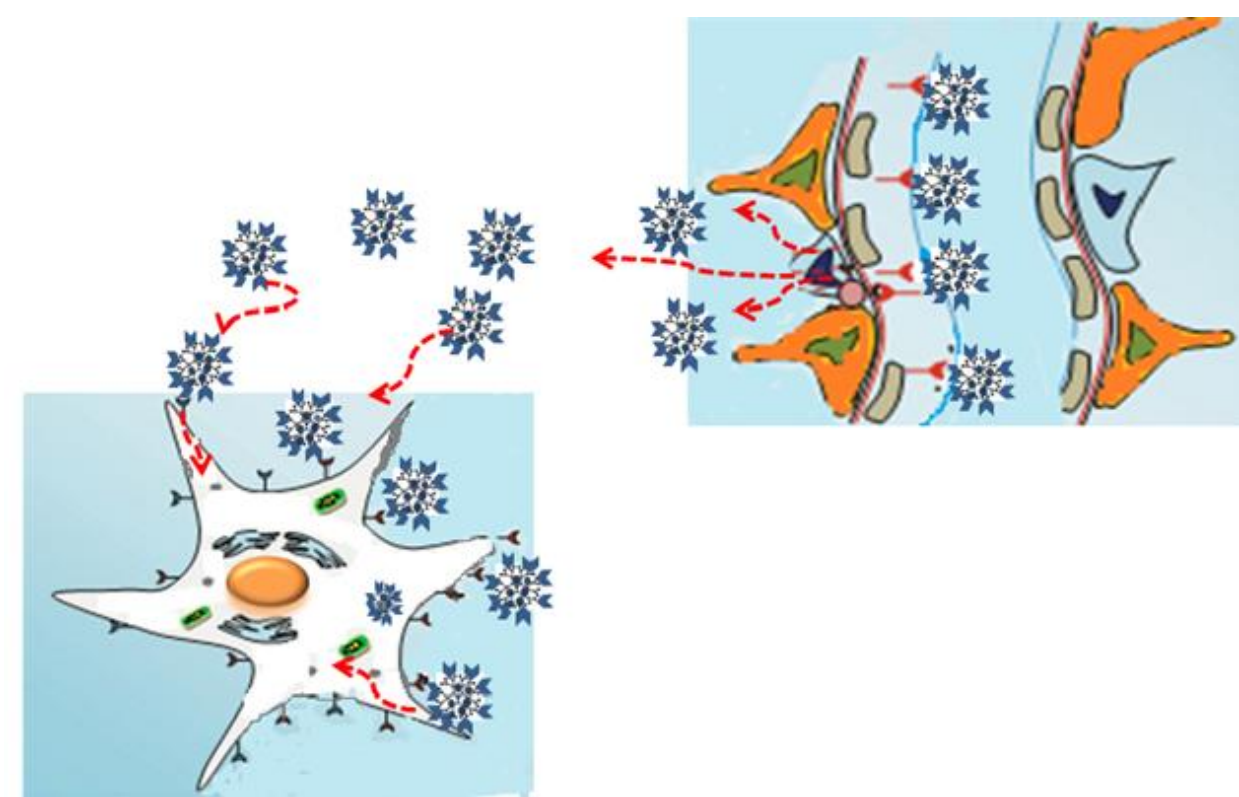

Figure 2. Schematic illustrates the transportation of Dendrimer-Phenylalanin across BBB and uptake by the brain tumor cell.

\section{Materials and Methods}

\subsection{Chemical materials.}

Phenylalanine (PA), Sephadex G-50, and 1-ethyl-3-(3-dimethyl aminopropyl) carbodiimide hydrochloride (EDC), sulfo-N-hydrosuccinimide (sulfo-NHS), triethylamine, dimethylformamide, MTT, and stannous chloride dihydrate were purchased from Sigma Chemicals (St Louis, MO, USA). Polyethylene glycol, citric acid anhydrous, sodium bicarbonate, methanol were purchased from Merck, Solvents, and chemical reagents were analytical grade from Merck.

\subsection{Cell culture.}

C6 cell line was supplied by the Pasteur Institute of Iran and used for cell cytotoxicity and imaging studies. The cells were cultured in complete RPMI-1640 medium, supplemented with $10 \%$ fetal bovine serum and $1 \%$ penicillin-streptomycin at $37^{\circ} \mathrm{C}$ with $5 \% \mathrm{CO}_{2}$. 


\subsection{Animal models.}

All animal experiments were done according to the guideline of the INMAS animal ethics committee. Miura et al. and Shahmabadi et al. protocols were used for tumor formation, 50.000 cells of C6 cells in $10 \mu \mathrm{l}$ of PBS were injected into the frontal lobe of the skull of a male rat $(200-250 \mathrm{~g}, \mathrm{n}=5)[9,77]$.

\subsection{Preparation of dendrimer G2-phenylalanine conjugate dendrimer $(G 2)$ synthesis.}

Dendrimer was synthesized using the method reported previously [26-28,59,61,62]. Briefly, polyethylene glycol (PEG) with two carboxyl groups on the sides formed the core, and citric acid formed the dendrimer's shell. PEG600, engineered Polyethylene glycol, (5.65 mmoles) was added to dried Dimethyl Sulfoxide (DMSO), and $\mathrm{Cacl}_{2}$ then mixed for 10 minutes. N, N'- Dicyclohexylcarbodiimide (DCC) (2mM) was added and mixed for 15 minutes. $0.5 \mathrm{gr}$ citric acid was added to the reaction container and stirred at $400 \mathrm{rpm}$ for $1 \mathrm{~h}$. In the next step, to synthesize the second generation, DCC ( $3 \mathrm{mM})$ was added. Then citric acid $(5.2 \mathrm{mM})$ was added to the reaction and stirred at $400 \mathrm{rpm}$ for 7 days. The color change to a dark brown color verified the synthesis of the $\mathrm{G}_{2}$ dendrimer. Filter paper, chromatography against Cephadex, and lyophilization were used to purify dendrimer (G2) purification.

\subsection{Conjugation phenylalanine on the surface of dendrimer $G 2$.}

The amine group of phenylalanine was covalently coupled to the carboxyl group of dendrimer $(\mathrm{G} 2)$, phenylalanine was decorated on the surface of the dendrimer. Briefly, the phenylalanine's free amine functional group reacts to carboxyl groups of the $G_{2}$ dendrimers via an amide bond. In the final step, the BODIPY (fluorescent dye) was loaded into the synthesized G2 dendrimer- phenylalanine (Figure 3). To remove the unentrapped Bodipy, the nanoparticle was dialyzed against DDW under sink conditions for $4 \mathrm{~h}$.

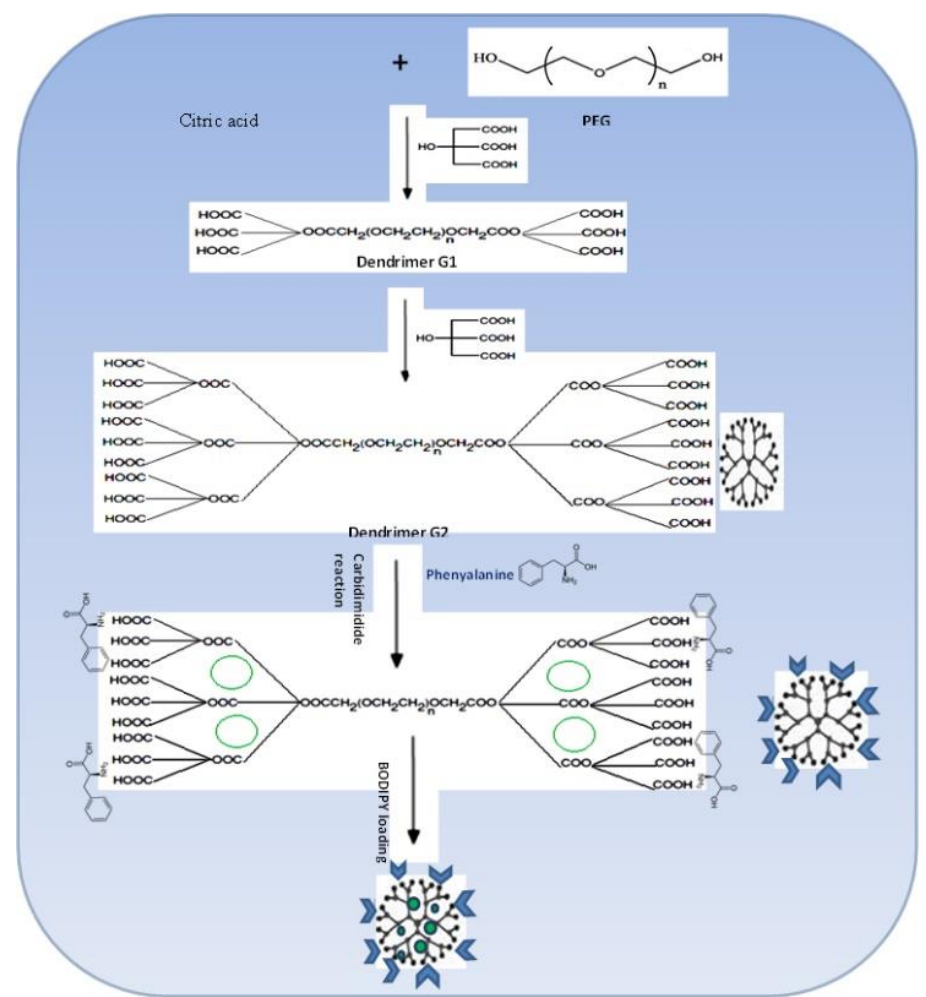

Figure 3. Schematic presentation of preparation of Dendrimer G2-Phenylalanine. 


\subsection{Characterization of nanoparticles.}

Mean size, size distribution, and zeta potential of particles were determined by Zetasizer (Zetasizer Nano ZS; Malvern Instruments, Malvern, UK). The conjugation of phenylalanine on the surface of Dendrimer G2 is confirmed by the FTIR analyses (NEXUS 870; Thermo Fisher Scientific, Waltham, MA, USA).

\section{7. ${ }^{99 m}$ Tc radio-labeling of dendrimer -phenylalanine conjugates.}

Dendrimers $(3.4 \mathrm{mg} / \mathrm{ml})$ in a sterile water suspension were labeled with $99 \mathrm{~m} \mathrm{Tc}$ pertechnetate $\left({ }^{99 \mathrm{~m}} \mathrm{TcO} 42\right)$ at $p H 3.4$, stannous chloride $\left(\mathrm{SnCl}_{2} \cdot 2 \mathrm{H}_{2} \mathrm{O}\right)$ has been used as a reducing agent. ${ }^{99 \mathrm{~m}} \mathrm{TcO} 42$ at $300-700 \mathrm{MBq} / 0.7 \mathrm{ml}$, eluted from a ${ }^{99} \mathrm{Mo} /{ }^{99 \mathrm{~m}} \mathrm{Tc}$ generator (DRN 4329; Ultratechnekow FM), was injected into a sterile vacuum collection vial, following, 0.5 $\mathrm{mg}$ of $\mathrm{SnCl}_{2} .2 \mathrm{H}_{2} \mathrm{O}$ was dissolved in $0.5 \mathrm{ml}$ of distilled water, and the solution was stirred for a few seconds and passed through a $0.22-\mathrm{mm}$ Millipore filter and was added into the vial containing the ${ }^{99 \mathrm{~m}} \mathrm{TcO}_{4-}$ nanoparticle, gently shaken for $30 \mathrm{~s}$ and incubated for $60 \mathrm{~min}$ at RT.

\subsection{Radiochemical purity.}

${ }^{99 m}$ Tc-dendrimer- Phenylalanine complex was analyzed with ITLC-SG using the method reported previously [26].

\subsection{In vitro cytotoxicity of dendrimer -phenylalanine.}

The in vitro cytotoxic effect of Dendrimer -Phenylalanine was examined using the 3(4,5-Dimethylthiazol-2-yl)-2,5-diphenyltetrazolium bromide (MTT) assay, using C6 glioma cell line. The cells were seeded at a density of $2 \times 10^{4}$ cells per well in 96 -well plates; then, the plates were incubated for $24 \mathrm{~h}$ in a humidified incubator with a $\mathrm{CO}_{2}$ concentration of $5 \%$ to permit adherence of the cells. Then, the cells were incubated either $0.1 \mathrm{ml}$ of medium containing Dendrimer -Phenylalanine at different iron concentrations $(0.125,0.25,0.5 \mathrm{mg} / \mathrm{ml})$ for $4 \mathrm{~h}$. After the incubation time, $10 \mu \mathrm{l}$ of $5 \mathrm{mg} / \mathrm{ml}$ MTT solution was added. Incubation was continued for a further $4 \mathrm{~h}$. Purple formazan crystals were (indicating cell viability) were solubilized by adding $100 \mu \mathrm{l}$ DMSO per well. The absorbance was measured at $570 \mathrm{~nm}$ by the Statfax-microplate reader (Statfax, Awareness Technology, Inc, USA). Experiments were performed in triplicate, and cell survival was determined as a percentage of viable cells in comparison with control wells. All assays were performed in triplicate for each concentration. Cell survival was determined as a percentage of viable cells compared to controls (cell line without ant treatment).

\subsection{Cellular uptake study.}

The uptake study was measured using a fluorescence-activated cell sorter (FACS) instrument (BD bioscience, FACSv Vantage California, USA).C6 glioma cell lines used in the study were cultured in the set of 12-well flat-bottom plates at a density of $3 \times 10^{5}$ cells/well, supplemented with $10 \% \mathrm{FBS}$ and $1 \%$ antibiotic and incubated at $37^{\circ} \mathrm{C}$ in a humidified atmosphere containing $5 \% \mathrm{CO}_{2}$ for $24 \mathrm{~h}$. Adhered cells were treated with Bodipy-loaded

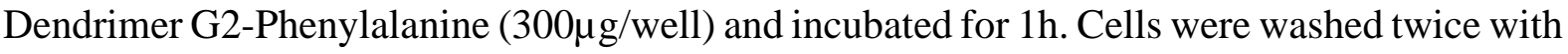
phosphate saline buffer (PBS, pH 7.4); the following cells were harvested by adding $1 \mathrm{ml}$ PBS 
( $\mathrm{pH}$ 7.4) sonicated five times to lysate the cells. Finally, cell lysate was centrifuged $(10,000$ rpm, 10min), the supernatant was used for fluorescence assay using FACS.

\subsection{SPECT scintigraphy in tumor-bearing Wistar rats.}

The rats were divided into two groups. The first group was treated with ${ }^{99 \mathrm{~m}} \mathrm{Tc}-$ unconjugated Dendrimer, and the second group with ${ }^{99 \mathrm{~m}} \mathrm{Tc}$-Dendrimer -phenylalanine. $1 \mathrm{ml}$ (3.7 MBq) of the labeled complex $(0.1 \mu \mathrm{M}$ of each complex) was administered to each group through the tail vein. Rats were then placed in the planar gamma camera, and images were taken at $1 \mathrm{~h}$ after injection.

\section{Results and Discussion}

\subsection{Characterization of nanoparticles.}

Zeta potential and size of dendrimer and dendrimer-phenylalanine were shown in table1. Significant change following the Phenylalanine conjugation was found $(74.14 \pm 2.2 \mathrm{~nm}$ and $-5.21 \pm 1.1 \mathrm{mv}$ to $104.9 \pm 3.1 \mathrm{~nm}$ and $-9.01 \pm 1.8 \mathrm{mv}$ respectively).

Table 1. Size and zeta potential distributions of the Dendrimer G2 and Dendrimer G2- Phenylalanine.

\begin{tabular}{l|c|c}
\multicolumn{1}{c|}{ Agent } & Size distribution, mean $(\mathbf{n m})$ & Zeta potential $(\mathbf{m v})$ \\
\hline Dendrimer G2 & $74.14 \pm 2.2$ & $-5.21 \pm 1.1$ \\
\hline Dendrimer G2- Phenylalanine & $104.9 \pm 3.1$ & $-9.1 \pm 1.8$
\end{tabular}

\subsection{FT-IR result.}

FT-IR results of Dendrimer G2 and Dendrimer Phenylalanine were compared and showed in Figure 4. The peaks between $3200-3600 \mathrm{~cm}^{-1}$ are related to $\mathrm{NH}$ and $\mathrm{OH}$ groups. The peak 1590-1760 wavelength shows carbonyl groups of the compound, aliphatic carbonhydrogen. $1738.4 \mathrm{~cm}^{-1}$ peak that exclusively depicts the dendrimer; this also is in dendrimer G2-Phenylalanine (Figure 4).

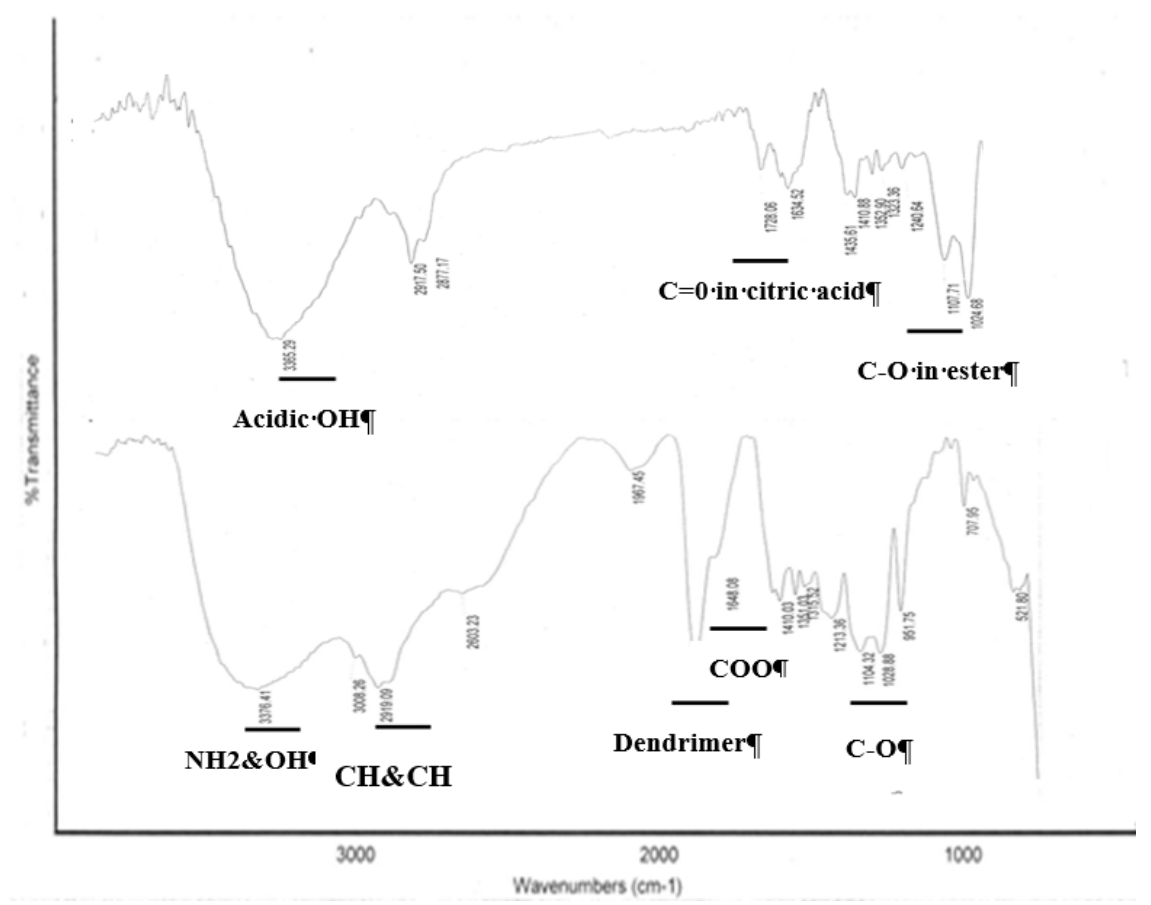

Figure 4. FT-IR spectrum of Dendrimer G2 and Dendrimer G2-Phenylalanine, respectively. Abbreviation:

FTIR: Fourier transform infrared spectroscopy. 


\subsection{In vitro cytotoxicity of nanoparticles.}

MTT assay was done on the C6 cell line to investigate the cytotoxic potential of nanoparticles. The results of the MTT assay exhibit no toxicity for Dendrimer G2Phenylalanine (Figure 5).

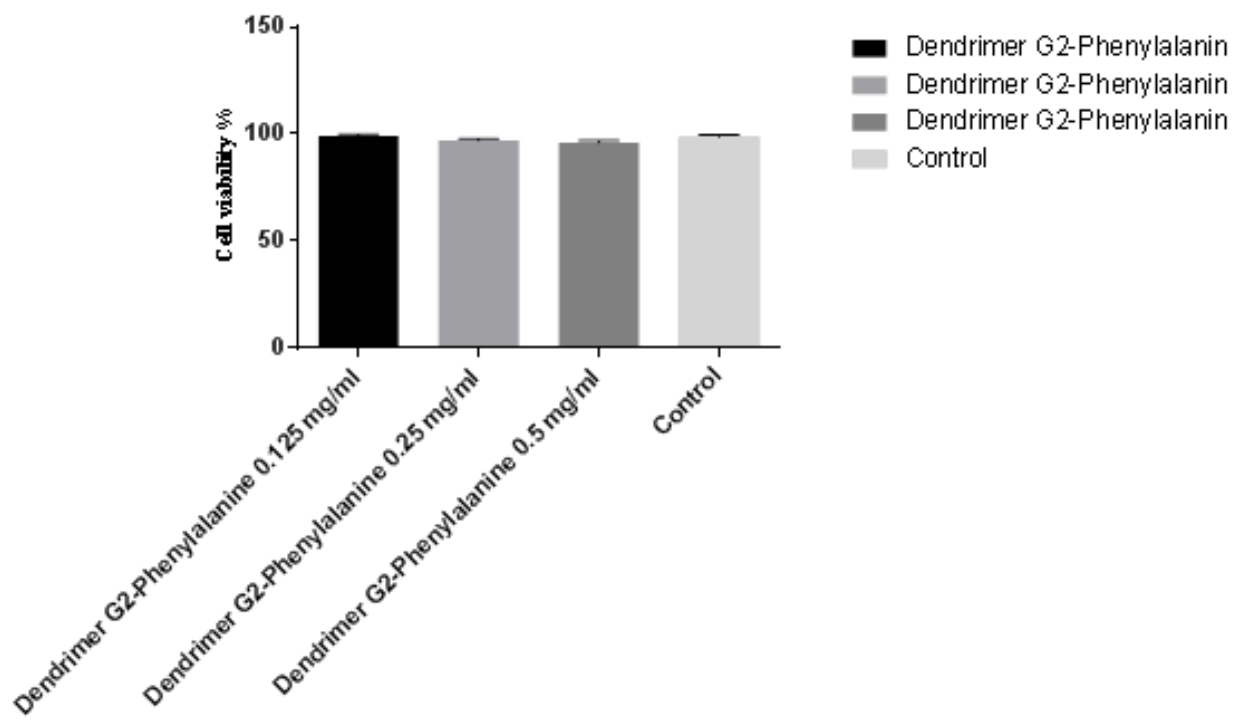

Figure 5. MTT cytotoxicity assay of Dendrimer G2-Phenylalanine measurement in different concentrations of nanoparticle $(0.125,0.25,0.5 \mathrm{mg} / \mathrm{ml})$. Abbreviation: MTT : 3-(4,5-Dimethylthiazol-2-Yl)-2,5-

Diphenyltetrazolium Bromide.

\subsection{Cellular uptake using flow cytometry.}

The flow cytometric analysis was utilized to verify the potential of G2-Phenylalanine to target LAT1 transporter that overexpressed on glioma cells. C6 cell line was incubated with G2-Phenylalanine-BODIPY nanoparticles $(300 \mu \mathrm{g})$, and cellular uptake was measured using fluorescence-activated cell sorter (FACS) instrument (BD bioscience, FACS vintage California, USA). 95.13 $\pm 0.6 \%$ and $98.02 \% \pm 0.8$ uptakes were observed with Dendrimer G2BODIPY and Dendrimer G2-Phenylalanine-BODIPY, respectively, after 1h (Figure 6).
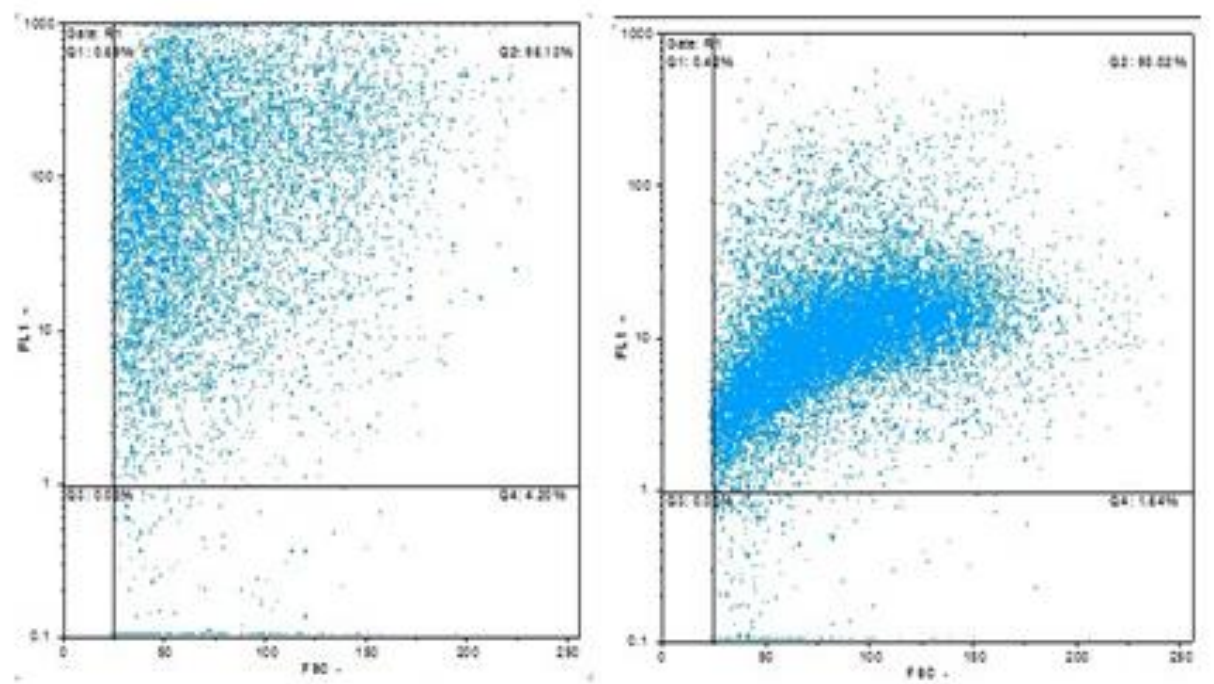

Figure 6. Flow cytometry studies for cellular uptake of Dendrimer G2-Phenylalanine-BODIPY and Dendrimer G2- loaded with BODIPY. Present PEG on the surface of Dendrimer promotes the uptake of nanoparticles $(95.13 \pm 0.6 \%)$. C6 cell line treated with G2-Phenylalanine-BODIPY exhibited strong green fluorescence $(98.02 \pm 0.8 \%)$. 
3.5. SPECT scintigraphy in tumor-bearing Wistar rats.

The planar and SPECT projections were made with Siemens Healthcare Global. The uptake of radioactivity in the brain of rat bearing C6 glioma cells after $1 \mathrm{~h}$ into the tail vein injection of Dendrimer G2 and Dendrimer G2-Phenylalanine was visualized on the images (Figure 7 and Table 2).
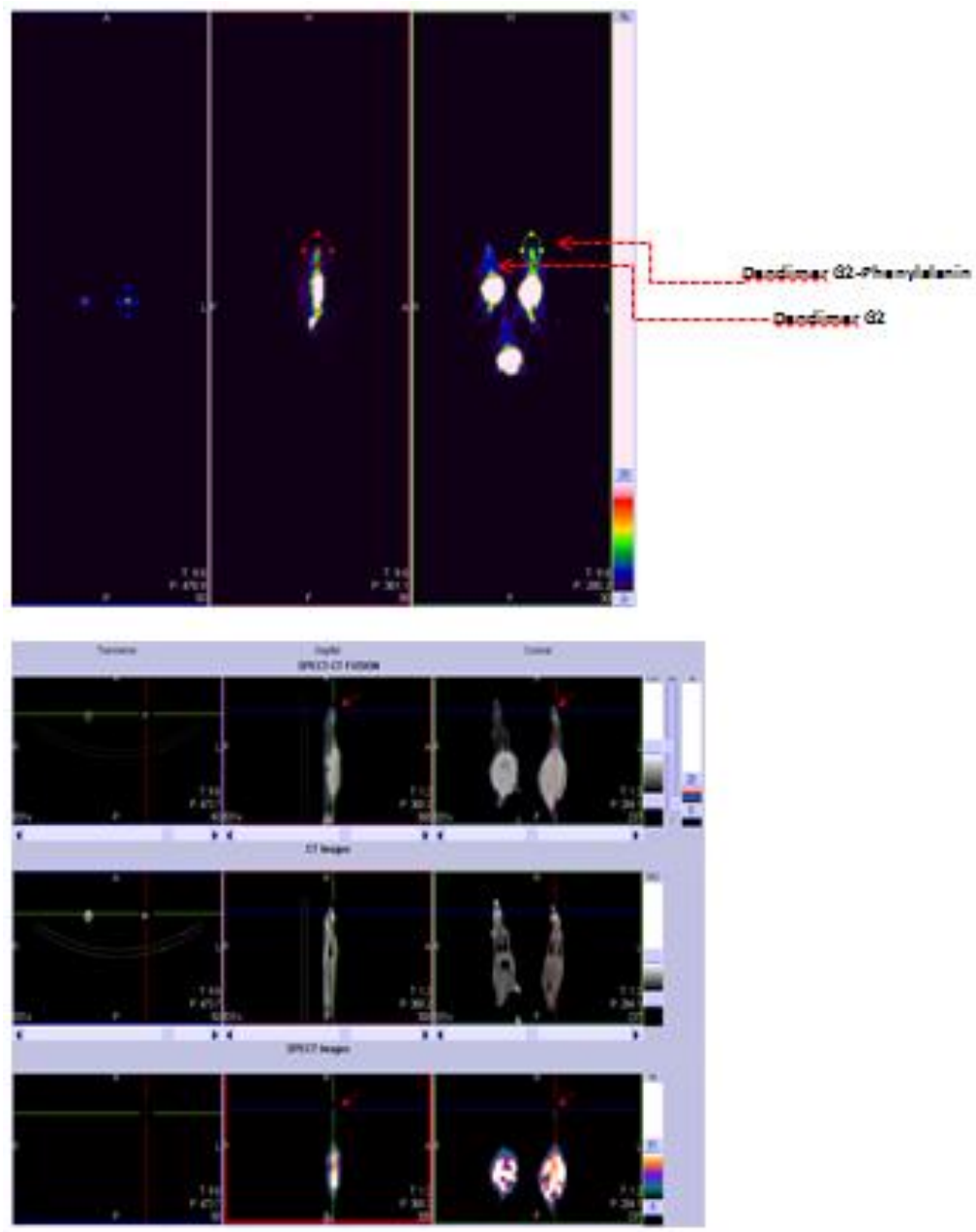

Figure 7. SPECT/CT images of rat bearing C6 glioma cells $1 \mathrm{~h}$ after injection with ${ }^{99 \mathrm{~m}}$ Tc-Dendrimer G2 AND ${ }^{99 m}$ Tc-Dendrimer G2-Phenylalanine. Abbreviation: SPECT: Single Photon Emission Computed Tomography.

Table 2 exhibits ${ }^{99 m}$ Tc count in Dendrimer G2, Dendrimer G2-Phenylalanine, and Dendrimer G2-

Phenylalanine / Dendrimer G2 ${ }^{99 \mathrm{~m}}$ Tc count ratio in the rat bearing C6 glioma cell's brain.

\begin{tabular}{l|c|c|c} 
& Dendrimer G2-Phenylalanine & Dendrimer G2 & Dendrimer G2-Phenylalanine / Dendrimer G2 ratio \\
\hline Max & 11053 & 6876 & 1.67 \\
\hline Min & 5668 & 3544 & 1.59 \\
\hline Ave & 7279.13 & 4594.83 & 1.58 \\
\hline Std. Dev & 1851.29 & 1314.3 &
\end{tabular}

\section{Conclusions}

The present study demonstrated the feasibility of labeling Dendrimer G2-Phenylalanine with ${ }^{99 \mathrm{~m}} \mathrm{Tc}$. Using in vitro and in vivo studies, we verified that the targeted Dendrimer G2 agent can deliver $99 \mathrm{mTc}$ through the BBB and preferentially target the glioma cells in a rat model of glioma. After the tail vein injection, the accumulation of ${ }^{99 \mathrm{~m}} \mathrm{TcDendrimer}$ G2-Phenylalanine was verified by SPECT/CT detection in the rat's brain. Our results provide a promising avenue for future researches toward finding novel approaches to treat neurological diseases. 


\section{Funding}

This work was supported by Students' Scientific Research Center, Tehran University of Medical Sciences, and Tehran University of Medical Sciences (Grant no. 94-03-61-30013) and International Campus, Tehran University of Medical Sciences (Grant no. 94-01-103-28528).

\section{Acknowledgments}

This research has no acknowledgment.

\section{Conflicts of Interest}

The authors declare no conflict of interest.

\section{References}

1. Huse, J.T.; Holland, E.; DeAngelis, L.M. Glioblastoma: molecular analysis and clinical implications. Annu. Rev. Med. 2013, 64, 59-70, https://doi.org/10.1146/annurev-med-100711-143028.

2. Adamson, C.; Kanu, O.O.; Mehta, A.I.; Di, C.; Lin, N.; Mattox, A.K.; Bigner, D.D. Glioblastoma multiforme: a review of where we have been and where we are going. Expert opinion on investigational drugs 2009, 18, 1061-1083, https://doi.org/10.1517/13543780903052764.

3. Kleihues, P.; Louis, D.N.; Scheithauer, B.W.; Rorke, L.B.; Reifenberger, G.; Burger, P.C.; Cavenee, W.K. The WHO classification of tumors of the nervous system. J. Neuropathol. Exp. Neurol. 2002, 61, 215-225, https://doi.org/10.1093/jnen/61.3.215.

4. Reardon, D.A.; Rich, J.N.; Friedman, H.S.; Bigner, D.D. Recent advances in the treatment of malignant astrocytoma. J. Clin. Oncol. 2006, 24, 1253-1265, https://doi.org/10.1200/JCO.2005.04.5302.

5. Burger, P.C.; Vogel, F.S.; Green, S.B.; Strike, T.A. Glioblastoma multiforme and anaplastic astrocytoma pathologic criteria and prognostic implications. Cancer 1985, 56, 1106-1111, https://doi.org/10.1002/10970142(19850901)56:5<1106::aid-cncr2820560525>3.0.co;2-2.

6. Wen, P.Y.; Kesari, S. Malignant gliomas in adults. New Engl. J. Med. 2008, 359, 492-507, https://doi.org/10.1056/NEJMra0708126.

7. Xu, L.W.; Chow, K.K.; Lim, M.; Li, G. Current vaccine trials in glioblastoma: a review. Journal of immunology research 2014, 2014, https://doi.org/10.1155/2014/796856.

8. Tian, X.-h.; Lin, X.-N.; Wei, F.; Feng, W.; Huang, Z.-C.; Wang, P.; Ren, L.; Diao, Y. Enhanced brain targeting of temozolomide in polysorbate- 80 coated polybutylcyanoacrylate nanoparticles. Int $J$ Nanomedicine 2011, 6, 445-452, https://doi.org/10.2147/IJN.S16570.

9. Shahmabadi, H.E.; Movahedi, F.; Esfahani, M.K.M.; Alavi, S.E.; Eslamifar, A.; Anaraki, G.M.; Akbarzadeh, A. Efficacy of Cisplatin-loaded polybutyl cyanoacrylate nanoparticles on the glioblastoma. Tumor Biol. 2014, 35, 4799-4806, https://doi.org/10.1007/s13277-014-1630-9.

10. Hawkins, B.T.; Davis, T.P. The blood-brain barrier/neurovascular unit in health and disease. Pharmacol. Rev. 2005, 57, 173-185, https://doi.org/10.1124/pr.57.2.4.

11. Brightman, M.; Reese, T.S. Junctions between intimately apposed cell membranes in the vertebrate brain. The Journal of cell biology 1969, 40, 648-677, https://doi.org/10.1083/jcb.40.3.648.

12. Crone, C.; Olesen, S. Electrical resistance of brain microvascular endothelium. Brain Res. 1982, 241, 49-55, https://doi.org/10.1016/0006-8993(82)91227-6.

13. Wong, H.L.; Wu, X.Y.; Bendayan, R. Nanotechnological advances for the delivery of CNS therapeutics. Adv. Drug Del. Rev. 2012, 64, 686-700, https://doi.org/10.1016/j.addr.2011.10.007.

14. Wong, H.L.; Chattopadhyay, N.; Wu, X.Y.; Bendayan, R. Nanotechnology applications for improved delivery of antiretroviral drugs to the brain. Adv. Drug Del. Rev. 2010, 62, 503-517, https://doi.org/10.1016/j.addr.2009.11.020.

15. Banks, W.A. Characteristics of compounds that cross the blood-brain barrier. BMC Neurol. 2009, 9, S3, https://doi.org/10.1186/1471-2377-9-S1-S3.

16. Pardridge, W.M. Crossing the blood-brain barrier: are we getting it right? Drug Discov. Today 2001, 6, 12, https://doi.org/10.1016/s1359-6446(00)01583-x.

17. Scherrmann, J.-M. Drug delivery to brain via the blood-brain barrier. Vascul. Pharmacol. 2002, 38, 349354, https://doi.org/10.1016/s1537-1891(02)00202-1.

18. Pardridge, W.M. Blood-brain barrier delivery. Drug Discov. Today 2007, 12, 54-61, https://doi.org/10.1016/j.drudis.2006.10.013.

19. Holman, D.W.; Klein, R.S.; Ransohoff, R.M. The blood-brain barrier, chemokines and multiple sclerosis. Biochimica et Biophysica Acta (BBA)-Molecular Basis of Disease 2011, 1812, 220-230, https://doi.org/10.1016/j.bbadis.2010.07.019.

https://biointerfaceresearch.com/ 
20. Garcel, A.; Martel, S.; Carrupt, P.A.; Doelker, E.; Delie, F. In vitro blood brain barrier models as a screening tool for colloidal drug delivery systems and other nanosystems. International Journal of Biomedical Nanoscience and Nanotechnology 2010, 1, 133-163, https://doi.org/10.1504/IJBNN.2010.034650.

21. Sharma, A.K.; Keservani, R.K.; Kesharwani, R.K. Nanobiomaterials: Applications in Drug Delivery; CRC Press: 2018.

22. Frank, R.T.; Aboody, K.S.; Najbauer, J. Strategies for enhancing antibody delivery to the brain. Biochimica et Biophysica Acta (BBA)-Reviews on Cancer 2011, 1816, 191-198, https://doi.org/10.1016/j.bbcan.2011.07.002.

23. Shah, L.; Yadav, S.; Amiji, M. Nanotechnology for CNS delivery of bio-therapeutic agents. Drug delivery and translational research 2013, 3, 336-351, https://doi.org/10.1007/s13346-013-0133-3.

24. Pardridge, W.M. Re-engineering biopharmaceuticals for delivery to brain with molecular Trojan horses. Bioconj. Chem. 2008, 19, 1327-1338, https://doi.org/10.1021/bc800148t.

25. Khosravian, P.; Ardestani, M.S.; Khoobi, M.; Ostad, S.N.; Dorkoosh, F.A.; Javar, H.A.; Amanlou, M. Mesoporous silica nanoparticles functionalized with folic acid/methionine for active targeted delivery of docetaxel. Onco Targets Ther. 2016, 9, 7315, https://doi.org/10.2147/OTT.S113815.

26. Khosroshahi, A.; Amanlou, M.; Sabzevari, O.; Daha, F.; Aghasadeghi, M.; Ghorbani, M.; Ardestani, M.; Alavidjeh, M.; Sadat, S.; Pouriayevali, M. A comparative study of two novel nanosized radiolabeled analogues of methionine for SPECT tumor imaging. Curr. Med. Chem. 2013, 20, 123-133.

27. Hashempour Alamdari, N.; Alaei-Beirami, M.; Shandiz, S.; Ataollah, S.; Hejazinia, H.; Rasouli, R.; Saffari, M.; Sadat Ebrahimi, S.E.; Assadi, A.; Shafiee Ardestani, M. Gd3+-Asparagine-Anionic Linear Globular Dendrimer Second-Generation G2 Complexes: Novel Nanobiohybrid Theranostics. Contrast Media Mol. Imaging 2017, 2017, https://doi.org/10.1155/2017/3625729.

28. Keshavarz, A.; Hajbabaei, S.; Sojoodi, J.; Saffari, M.; Afshar, M.A.A.; Monnavari, F.; Pargoo, E.M.; Rasouli, R.; Hejazinia, H.; Assadi, A. Mn 2+-Negatively Charged Pegylated Dendrimer G2-Tryptophan: Novel Nano Magnetic Resonance Imaging Agent. Advances in Applied Physiology 2017, 2, 1, https://doi.org/10.11648/j.aap.20170201.11.

29. Li, L.; Di, X.; Wu, M.; Sun, Z.; Zhong, L.; Wang, Y.; Fu, Q.; Kan, Q.; Sun, J.; He, Z. Targeting tumor highly-expressed LAT1 transporter with amino acid-modified nanoparticles: toward a novel active targeting strategy in breast cancer therapy. Nanomed. Nanotechnol. Biol. Med. 2017, 13, 987-998, https://doi.org/10.1016/j.nano.2016.11.012.

30. Li, L.; Di, X.; Zhang, S.; Kan, Q.; Liu, H.; Lu, T.; Wang, Y.; Fu, Q.; Sun, J.; He, Z. Large amino acid transporter 1 mediated glutamate modified docetaxel-loaded liposomes for glioma targeting. Colloids Surf. B. Biointerfaces 2016, 141, 260-267, https://doi.org/10.1016/j.colsurfb.2016.01.041.

31. Fernandes, J.; Ghate, M.V.; Mallik, S.B.; Lewis, S.A. Amino acid conjugated chitosan nanoparticles for the brain targeting of a model dipeptidyl peptidase-4 inhibitor. Int. J. Pharm. 2018, https://doi.org/10.1016/j.ijpharm.2018.06.031.

32. Ong, Z.Y.; Chen, S.; Nabavi, E.; Regoutz, A.; Payne, D.J.; Elson, D.S.; Dexter, D.T.; Dunlop, I.E.; Porter, A.E. Multibranched gold nanoparticles with intrinsic lat-1 targeting capabilities for selective photothermal therapy of breast cancer. ACS applied materials \& interfaces 2017, 9, 39259-39270, https://doi.org/10.1021/acsami.7b14851.

33. Kharya, P.; Jain, A.; Gulbake, A.; Shilpi, S.; Jain, A.; Hurkat, P.; Majumdar, S.; Jain, S.K. Phenylalaninecoupled solid lipid nanoparticles for brain tumor targeting. J. Nanopart. Res. 2013, 15, 1-12, https://doi.org/10.1007/s11051-013-2022-6.

34. Christensen, H.N. Role of amino acid transport and countertransport in nutrition and metabolism. Physiol. Rev. 1990, 70, 43-77, https://doi.org/10.1152/physrev.1990.70.1.43.

35. del Amo, E.M.; Urtti, A.; Yliperttula, M. Pharmacokinetic role of L-type amino acid transporters LAT1 and LAT2. Eur. J. Pharm. Sci. 2008, 35, 161-174, https://doi.org/10.1016/j.ejps.2008.06.015.

36. Russell, H.; Taylor, P.M.; Hundal, H.S. Amino acid transporters: roles in amino acid sensing and signalling in animal cells. Biochem. J. 2003, 373, 1-18, https://doi.org/10.1042/bj20030405.

37. Yoon, J.H.; Kim, Y.B.; Kim, M.S.; Park, J.C.; Kook, J.K.; Jung, H.M.; Kim, S.G.; Yoo, H.; Ko, Y.M.; Lee, S.H. Expression and functional characterization of the system L amino acid transporter in KB human oral epidermoid carcinoma cells. Cancer Lett. 2004, 205, 215-226, https://doi.org/10.1016/j.canlet.2003.10.009.

38. Ohkame, H.; Masuda, H.; Ishii, Y.; Kanai, Y. Expression of L-type amino acid transporter 1 (LAT1) and 4F2 heavy chain (4F2hc) in liver tumor lesions of rat models. J. Surg. Oncol. 2001, 78, 265-272, https://doi.org/10.1002/jso.1165.

39. Lin, J.; Raoof, D.A.; Thomas, D.G.; Greenson, J.K.; Giordano, T.J.; Robinson, G.S.; Bourner, M.J.; Bauer, C.T.; Orringer, M.B.; Beer, D.G. L-type amino acid transporter-1 overexpression and melphalan sensitivity in Barrett's adenocarcinoma. Neoplasia 2004, 6, 74-84, https://doi.org/10.1016/S1476-5586(04)80054-X.

40. Nawashiro, H.; Otani, N.; Shinomiya, N.; Fukui, S.; Ooigawa, H.; Shima, K.; Matsuo, H.; Kanai, Y.; Endou, H. L-type amino acid transporter 1 as a potential molecular target in human astrocytic tumors. Int. J. Cancer 2006, 119, 484-492, https://doi.org/10.1002/ijc.21866. 
41. Nawashiro, H.; Otani, N.; Shinomiya, N.; Fukui, S.; Nomura, N.; Yano, A.; Shima, K.; Matsuo, H.; Kanai, Y. The role of CD98 in astrocytic neoplasms. Hum. Cell 2002, 15, 25-31, https://doi.org/10.1111/j.17490774.2002.tb00096.x.

42. Nakanishi, K.; Matsuo, H.; Kanai, Y.; Endou, H.; Hiroi, S.; Tominaga, S.; Mukai, M.; Ikeda, E.; Ozeki, Y.; Aida, S. LAT1 expression in normal lung and in atypical adenomatous hyperplasia and adenocarcinoma of the lung. Virchows Archiv 2006, 448, 142-150, https://doi.org/10.1007/s00428-005-0063-7.

43. Yoon, J.H.; Kim, I.J.; Kim, H.; Kim, H.-J.; Jeong, M.J.; Ahn, S.G.; Kim, S.A.; Lee, C.H.; Choi, B.K.; Kim, J.-K. Amino acid transport system L is differently expressed in human normal oral keratinocytes and human oral cancer cells. Cancer Lett. 2005, 222, 237-245, https://doi.org/10.1016/j.canlet.2004.09.040.

44. Kim, S.-G.; Kim, H.-H.; Kim, H.-K.; Kim, C.-H.; Chun, H.S.; Kanai, Y.; Endou, H.; Do Kyung, K. Differential expression and functional characterization of system $\mathrm{L}$ amino acid transporters in human normal osteoblast cells and osteogenic sarcoma cells. Anticancer Res. 2006, 26, 1989-1996.

45. Gonzalez-Carter, D.A.; Ong, Z.Y.; McGilvery, C.M.; Dunlop, I.E.; Dexter, D.T.; Porter, A.E. L-DOPA functionalized, multi-branched gold nanoparticles as brain-targeted nano-vehicles. Nanomed. Nanotechnol. Biol. Med. 2019, 15, 1-11, https://doi.org/10.1016/j.nano.2018.08.011.

46. Maekawa-Matsuura, M.; Fujieda, K.; Maekawa, Y.; Nishimura, T.; Nagase, K.; Kanazawa, H. LAT1targeting thermoresponsive liposomes for effective cellular uptake by cancer cells. ACS Omega 2019, 4, 6443-6451, https://doi.org/10.1021/acsomega.9b00216.

47. Wang, D.; Zhao, Q.; Jiang, T.; Sha, L.; Wang, S.; Song, Y. Large amino acid transporter 1 mediated glutamate modified mesoporous silica nanoparticles for chemophotothermal therapy. J. Drug Deliv. Sci. Technol. 2019, 52, 784-793, https://doi.org/10.1016/j.jddst.2019.05.043.

48. Puris, E.; Gynther, M.; Auriola, S.; Huttunen, K.M. L-Type amino acid transporter 1 as a target for drug delivery. Pharm. Res. 2020, 37, https://doi.org/10.1007/s11095-020-02826-8.

49. Rosilio, C., M. Nebout, V. Imbert, E. Griessinger, Z. Neffati, J. Benadiba, T. Hagenbeek et al. L-type aminoacid transporter 1 (LAT1): a therapeutic target supporting growth and survival of T-cell lymphoblastic lymphoma/T-cell acute lymphoblastic leukemia. Leukemia 2015, 29, 1253-1266, https://doi.org/10.1038/leu.2014.338 .

50. Zhang, L.; Sui, C.; Yang, W.; Luo, Q. Amino acid transporters: Emerging roles in drug delivery for tumortargeting therapy. Asian Journal of Pharmaceutical Sciences 2020, https://doi.org/10.1016/j.ajps.2019.12.002.

51. Häfliger, P.; Charles, R.-P. The L-type amino acid transporter LAT1-An emerging target in cancer. Int. J. Mol. Sci. 2019, 20, 2428, https://doi.org/10.3390/ijms20102428.

52. Mészáros, M. Targeting the blood-brain barrier with solid and vesicular nanoparticles decorated with ligands of solute carriers. szte, 2019.

53. Rasouli, R.; Grüttner, C.; Ardestani, M.S.; Faridi-Majidi, R. Preparation and Evaluation of New LAT1Targeted USPION to Improve Sensitivity and Specificity in Metabolic Magnetic Imaging of Breast Cancer. Biointerface Research in Applied Chemistry 2021, 10248 - 10264.

54. Rautio, J.; Laine, K.; Gynther, M. Enhanced brain drug delivery and targeting. Pharmaceutical Technology Europe 2008, 1, 3.

55. Misra, A.; Ganesh, S.; Shahiwala, A.; Shah, S.P. Drug delivery to the central nervous system: a review. J. Pharm. Pharm. Sci. 2003, 6, 252-273.

56. Boado, R.J.; Li, J.Y.; Nagaya, M.; Zhang, C.; Pardridge, W.M. Selective expression of the large neutral amino acid transporter at the blood-brain barrier. Proceedings of the National Academy of Sciences 1999, 96, 12079-12084, https://doi.org/10.1073/pnas.96.21.12079.

57. Fathi, S.; Saber, R.; Adabi, M.; Rasouli, R.; Douraghi, M.; Morshedi, M.; Farid-Majidi, R. Novel Competitive Voltammetric Aptasensor Based on Electrospun Carbon Nanofibers-Gold Nanoparticles Modified Graphite Electrode for Salmonella enterica serovar Detection. Biointerface Research in Applied Chemistry 2021, 8702-8715.

58. Alavidjeh, M.S.; Haririan, I.; Khorramizadeh, M.R.; Ghane, Z.Z.; Ardestani, M.S.; Namazi, H. Anionic linear-globular dendrimers: biocompatible hybrid materials with potential uses in nanomedicine. J. Mater. Sci. Mater. Med. 2010, 21, 1121-1133, https://doi.org/10.1007/s10856-009-3978-8.

59. Haririan, I.; Alavidjeh, M.S.; Khorramizadeh, M.R.; Ardestani, M.S.; Ghane, Z.Z.; Namazi, H. Anionic linear-globular dendrimer-cis-platinum (II) conjugates promote cytotoxicity in vitro against different cancer cell lines. Int J Nanomedicine 2010, 5, 63-75, https://doi.org/10.2147/ijn.s8595.

60. Amanlou, M.; Siadat, S.D.; Ebrahimi, S.; Alavi, A.; Aghasadeghi, M.R.; Ardestani, M.S.; Shanehsaz, S.; Ghorbani, M.; Mehravi, B.; Alavidjeh, M.S. Gd3+-DTPA-DG: novel nanosized dual anticancer and molecular imaging agent. Int J Nanomedicine 2011, 6, 747-763, https://doi.org/10.2147/IJN.S17648.

61. Darvish Mohamadi, T.; Amanlou, M.; Ghalandarlaki, N.; Mehravi, B.; Shafiee Ardestani, M.; Yaghmaei, P. -DTPA-Meglumine-Anionic Linear Globular Dendrimer G1: Novel Nanosized Low Toxic Tumor Molecular MR Imaging Agent. ISRN pharmaceutics 2013, 2013, https://doi.org/10.1155/2013/378452.

62. Kebriaezadeh, A.; Ashrafi, S.; Rasouli, R.; Ebrahimi, S.E.S.; Hamedani, M.P.; Assadi, A.; Saffari, M.; Ardestani, M.S. Gadobutrol-dendrimer effects on metastatic and apoptotic gene expression. Advances in nano research 2016, 4, 145-156, https://doi.org/10.12989/anr.2016.4.2.145. 
63. Akbarian, S.; Sojoodi, J.; Monnavari, F.; Heidari, H.; Khosravian, P.; A Javar, H.; Assadi, A.; Rasouli, R.; Saffari, M.; AS Shandiz, S. Nano Conjugated PLGA-Chlorambucil: Synthesis In Vitro Anti Non-Hodgkin's Lymphoma Cellular Assay. Letters in Drug Design \& Discovery 2017, 14, 827-836, https://doi.org/10.2174/1570180814666161130113446.

64. Ebrahimi, S.H.; Rasouli, R.; Alavi, S.E.; Akbarzadeh, A.; Koohi, M.E.M. Investigation Of Effective Factors In Preparation Of Polybutyl Cyanoacrylate Nanoparticles By Emulsion Polymerization. New Cellular \& Molecular Biotechnology Journal 2015, 5, 33-38.

65. Hosseinian, Z.; Rasouli, R.; Azarnoosh, A.; Mortazavi, M.; Akbarzadeh, A. Evaluation of magnetic nanoparticles loaded with cisplatin Performance on breast cancer in In vivo and in vitro studies. NCMBJ 2015, 5, 29-36.

66. Rasouli, R.; Barhoum, A.; Uludag, H. A review of nanostructured surfaces and materials for dental implants: surface coating, patterning and functionalization for improved performance. Biomaterials science 2018, 6 , 1312-1338, https://doi.org/10.1039/c8bm00021b.

67. Rasouli, R.; Barhoum, A.; Bechelany, M.; Dufresne, A. Nanofibers for Biomedical and Healthcare Applications. Macromol. Biosci. 2019, 19, 1800256, https://doi.org/10.1002/mabi.201800256.

68. Barhoum, A.; Rasouli, R.; Yousefzadeh, M.; Rahier, H.; Bechelany, M. Nanofiber Technology: History and Developments. Handbook of Nanofibers 2018, 3-43.

69. Rasouli, R.; Barhoum, A. Advances in Nanofibers for Antimicrobial Drug Delivery. Handbook of Nanofibers 2018, 733-744.

70. Rasouli, R.; Alaei-Beirami, M.; Zaaeri, F. Nanobased Cns Delivery Systems. In: Nanobiomaterials. Apple Academic Press: 2018; pp. 441-473.

71. Rasouli, R.; Alikhani, Z.; Shafiee, A.M.; Faridi, M.R.; Ebrahimi, S.F. Nanotechnology In The Development Of Vaccines. 2015.

72. Nozaki, S.; Nakatani, Y.; Mawatari, A.; Shibata, N.; Hume, W.E.; Hayashinaka, E.; Wada, Y.; Doi, H.; Watanabe, Y. 18 F-FIMP: a LAT1-specific PET probe for discrimination between tumor tissue and inflammation. Sci. Rep. 2019, 9, 1-9, https://doi.org/10.1038/s41598-019-52270-x.

73. Verhoeven, J.; Baguet, T.; Piron, S.; Pauwelyn, G.; Bouckaert, C.; Descamps, B.; Raedt, R.; Vanhove, C.; De Vos, F.; Goethals, I. 2-[18F] FELP, a novel LAT1-specific PET tracer, for the discrimination between glioblastoma, radiation necrosis and inflammation. Nucl. Med. Biol. 2020, 82, 9-16, https://doi.org/10.1016/j.nucmedbio.2019.12.002.

74. von Schulthess, G.K.; Steinert, H.C.; Hany, T.F. Integrated PET/CT: current applications and future directions 1. Radiology 2006, 238, 405-422, https://doi.org/10.1148/radiol.2382041977.

75. Catana, C.; Wu, Y.; Judenhofer, M.S.; Qi, J.; Pichler, B.J.; Cherry, S.R. Simultaneous acquisition of multislice PET and MR images: initial results with a MR-compatible PET scanner. J. Nucl. Med. 2006, 47, 1968-1976.

76. Weber, W.A.; Grosu, A.L.; Czernin, J. Technology insight: advances in molecular imaging and an appraisal of PET/CT scanning. Nat. Clin. Pract. Oncol. 2008, 5, 160-170, https://doi.org/10.1038/ncponc1041.

77. Miura, F.K.; Alves, M.J.F.; Rocha, M.C.; Silva, R.S.; Oba-Shinjo, S.M.; Uno, M.; Colin, C.; Sogayar, M.; Marie, S.K. Experimental nodel of C6 brain tumors in athymic rats. Arq. Neuropsiquiatr. 2008, 66, 238-241, https://doi.org/10.1590/s0004-282x2008000200019. 